\title{
Present Status of Bacterial Diseases of Rainbow Trout, Oncorhynchus mykiss, in Turkey
}

\author{
Gulsen Ulukoy $^{1 \S} \quad$ Pinar Yildirim² $^{2} \quad$ Aysegul Kubilay $^{2}$, \\ ${ }^{1}$ Department of Aquaculture, Diseases Division, Faculty of Fisheries, Muğla SitkıKocman University, \\ Muğla-TURKEY, 48000. \\ ${ }^{2}$ Department of Aquaculture, Faculty of Fisheries, SüleymanDemirel University, \\ Isparta-TURKEY, 32260
}

\begin{abstract}
In this review, Our aim was to determine different aspects of the most threatening bacterial diseases of rainbow trout culture in freshwater systems. In Turkey, aquaculture has started in the 1970s by farming the rainbow trout. It is one of the most important freshwater species. The recent knowledge about the value of production of rainbow trout in our country found to be 111, 335 tons in 2012 and 122,873 tons in 2013 which showed an increasing trend until 2014 by each year. Depending upon the production in intensive culture of fish has led to outbreaks of some bacterial diseases which causes economical losses in trout farms. The most important bacterial diseases reported as yersiniosis, vibriosis, motile Aeromonas septisemia, lactocococosis, flavobacteriosis. We obtained a review of the literature that focuses on the bacterial diseases which have been reported as outbreaks in rainbow trout farms up to now. When the reports evaluated Flavobacterium psyrophilum found to be most pathogenic bacteria in the rainbow trout hatcheries. The current studies on developing a vaccine and vaccination methodology to be able to prevent bacterial diseases are also addressed.
\end{abstract}

${ }^{\S}$ Corresponding author Tel: +90 2522111519; Fax: 902522111887

E-Mail Adres: gulukoy@mu.edu.tr 